\title{
O NEOCONSTITUCIONALISMO E A ABSORÇÃO CULTURAL DOS POVOS ORIGINÁRIOS PARA PROTEÇÃO DA FLORESTA AMAZÔNICA
}

\author{
NEOCONSTITUTIONALISM AND THE CULTURAL ABSORPTION OF THE \\ ORIGINATING PEOPLES FOR THE PROTECTION OF THE AMAZON FOREST
}

\section{Fernando Barotti dos Santos}

Mestre em Direito Ambiental e Desenvolvimento Sustentável pela Escola Superior Dom Helder Câmara - ESDHC (2019). Bacharel em Direito, ESDHC (2016).

\section{Luiz Gustavo Gonçalves Ribeiro}

Doutorado em Direito pela Universidade Federal de Minas Gerais - UFMG (2008). Mestrado - UFMG (2005). Especialização em Ciências Penais pela Universidade José do Rosário Vellano - UNIFENAS. É docente de Direito Penal do curso de Graduação e de Direito Penal Ambiental dos cursos de Mestrado e Doutorado em Direito Ambiental e Desenvolvimento Sustentável da Escola Superior Dom Helder Câmara. Promotor de Justiça do Ministério Público do Estado de Minas Gerais.

\section{Resumo}

A proposta do artigo é evidenciar como o modelo neoconstitucional dos países da América Latina, em especial os que se encontram na região Amazônica, serve como marco importante de proteção ambiental. Este estudo parte da avaliação de que o novo constitucionalismo latino avança na proteção da Floresta Amazônica, e mais do que isso aceita a complexidade existente em seu povo. Dessa forma, a pesquisa evidencia o papel das comunidades originárias na atualização e efetiva proteção ambiental, trazendo o seu modelo cultural e seus saberes para o mundo jurídico. O neoconstitucionalismo é o paradigma que aceita a pluralidade e a diferença, a fim de construir uma sociedade melhor e uma proteção da Pan-Amazônia mais eficiente. O trabalho utiliza a metodologia jurídico-teórica e o raciocínio dedutivo, por meio de pesquisa bibliográfica. Conclui-se que o neoconstitucionalismo latino é importante para integrar os saberes e melhor proteger o meio ambiente.

Palavras-chave: Neoconstitucionalismo. Povos Originários. Constituições. Pan-Amazônia. 


\begin{abstract}
The purpose of this article is to show how the neoconstitutional model of Latin American countries, especially those in the Amazon region, serves as an important landmark in environmental protection. This study starts from the evaluation that the new Latin constitutionalism advances in the protection of the Amazonian forest, and more than that, it accepts the complexity existing in its people. In this way, the research evidences the role of the original communities in updating and effective environmental protection, bringing their cultural model and their knowledge to the legal world. Neo-constitutionalism is the paradigm that accepts plurality and difference, in order to build a better society and better protection of the Pan-Amazon. The work uses the legal-theoretical methodology and the deductive reasoning, through bibliographical research. Concluding that Latin neoconstitutionalism is important to integrate knowledge and better protect the environment.
\end{abstract}

Keywords: Neo-constitutionalism. Original Peoples. Constitutions. Pan-Amazon.

\title{
1. CONSIDERAÇÕES INICIAIS
}

O artigo estuda como o modelo do novo constitucionalismo na América Latina possibilita a proteção do meio ambiente. Para isso, a pesquisa submerge na proteção alcançada pelas constituições dos países latinos que integram a região da Floresta Amazônica e que participaram de um movimento de mudança paradigmática, introduzindo uma nova concepção constitucional de preservação ambiental, encontrando, sobretudo nos povos tradicionais, uma rica fonte de saber capaz de auxiliar o Direito em seu objetivo nacional e internacional de amparo a esse bem essencial que é a Amazônia.

O marco da pesquisa se dá com base no pensamento neoconstitucional estabelecido nas constituições latinas; o trabalho observa como esses saberes produzidos por povos tradicionais da região amazônica podem suscitar a preservação ambiental mais ampla e dinâmica, evidenciando uma participação política e jurídica desses grupos. A pesquisa propõe-se a visualizar e a descrever como essas constituições abarcam o pluralismo cultural, a decolonialidade e a percepção de uma proteção ambiental pelas diferenças culturais.

$O$ trabalho se divide em três itens. No primeiro analisa-se o que é o movimento constitucional, descrevendo-se sua evolução, desde a Magna Carta de 1215, assinada por João Sem Terra, até o modelo constitucional americano- 
europeu, originando o modelo constitucional latino. Logo, esse parâmetro constitucional que perdurou até a redemocratização de muitos desses países foi substituído pelo neoconstitucionalismo, um novo paradigma que permite a abertura para a sociedade que realmente existe e suas diferenças ao que antes existia como parâmetro constitucional.

O segundo item expõe um estudo das constituições dos países da PanAmazônia que integram o modelo neoconstitucional, evidenciando como abordam em seus textos a proteção ambiental, bem como a citada floresta e o pluralismo cultural. Por fim, o último item visa a esta integração entre sistema jurídico e os saberes tradicionais desses povos, para melhor conceber uma proteção ao meio ambiente, efetivando os ditames das normas constitucionais apresentadas, possibilitando uma integração interna e internacional, uma rede desses países e de seus povos e uma troca cultural e jurídica plural e dinâmica.

O trabalho revisitou pensadores que concebem a integração inter e transdisciplinar, lançando mão de metodologia jurídico-teórica, tendo como base o pensamento neoconstitucional; usou-se o raciocínio dedutivo, por meio de pesquisas bibliográficas e das constituições dos países em tela.

\section{UM PANORAMA DO MOVIMENTO CONSTITUCIONAL E A SUA ATUALIDADE}

Ao falar em Constituição, deve-se entender que ela não nasce ou se propõe automaticamente no mundo fático do Direito, é fruto do desenvolvimento político, social e jurídico, diante de "[...] uma sucessão de eventos de violência e de processos de mais longa maturação, objetivando primeiramente, opor limites ao poder absoluto do rei, simultaneamente adotando uma legitimação leiga [...]" (CERQUEIRA, 1993, p. 13). O estudo constitucional implica observar o passado, em que o paradigma era a supremacia da legalidade da lei, a mudança contextual que deu origem ao texto fundamental, que gera, define, contém e delimita uma sociedade, que busca limitar poderes de autoridades e ao mesmo tempo consagrar e evidenciar direitos e deveres.

Examinar o movimento constitucional é igualmente importante para compreender sua origem, o que foi superado dentro da teoria jurídica constitucional, seus paradigmas atuais e aquilo que ainda não está compreendido em seu texto. 
Desde a Magna Carta de 1215, assinada pelo rei João Sem Terra da Inglaterra, referência embrionária do pensamento constitucional (DALLARI, 2011), até o que teóricos chamam de novo constitucionalismo, existe uma proposta de proteção de direitos individuais, sociais, difusos, coletivos, transgeracionais ou transfronteiriços (BARROSO, 2013), a depender de cada cultura ${ }^{1}$ e momento social.

A formatação constitucional avançou com a Revolução Inglesa no século XVII, com a primeira Constituição escrita do Estado da Virgínia em 1776, com o texto constitucional dos Estados Unidos da América (EUA) em 1787 e a francesa, de 1789 (DALLARI, 2011). A presença da Constituição, que conjuga objetivos fundamentais, direitos e restrições à atuação do Estado, permitiu ao constitucionalismo ser revolucionário, retirou das leis a sua força imperativa, ou seja, o princípio da legalidade que se encontrava como primazia do Estado Legislativo de Direito agora está compreendido e subordinado ao texto de uma Constituição.

Portanto, o que se conhece como "o conceito moderno de Constituição somente emergiria no contexto das revoluções de fins do século XVIII. Mais precisamente, no âmbito dos debates coloniais, na América Inglesa, sobre as medidas impostas pela metrópole" (OLIVEIRA; GOMES, 2011, p. 131). O constitucionalismo abrigou uma nova visão jurídica; a sociedade, a política, os interesses individuais e de grupos não só formulam um documento, que em tenso acordo subordinaria a todos, mas como igualmente seriam eles gerenciados e limitados por esse texto normativo, visto quea convivência humana é conflituosa e resulta da interação e da possibilidade até mesmo de autoconflito (OLIVEIRA, 2016). Dessa forma, suas ambições e divergências são reguladas dentro de seus próprios filtros presentes na Constituição².

Contudo, ao trabalhar com a ideia de movimento constitucional, observa-se que o constitucionalismo contemporâneo, levado principalmente pela Revolução Francesa e a Independência dos EUA, não foi capaz de resolver ou absorver todo o

\footnotetext{
${ }^{1}$ Para essa pesquisa, é a afirmação da cultura como síntese de conhecimentos, crenças, arte, moral, costumes e outras capacidades ou hábitos adquiridos pelo homem enquanto membro da sociedade; desenvolveu-se a ideia de que, dentre esse conjunto de expressões culturais, há algumas sobre as quais o direito deve incidir (MARCHESAN, 2007, p. 26). São, portanto, todos os complexos de conhecimento, crenças, artes, leis, costumes e outras habilidades adquiridas pelos seres humanos e também em decorrência da sua sociedade.

$2 \mathrm{O}$ conflito entre os indivíduos é percebido por pensadores da teoria da constituição e levado a discutir o papel da constituição e de seu poder constituinte: "Ao compreendermos o lugar da soberania como um lugar de indistinção entre o dentro e o fora, como uma zona de inerradicável tensão, então é possível pensá-la em termos(CHUEIRI; GODOY, 2010, p. 163).
} 
paradigma que se impunha na sociedade. Talvez, em detrimento do período de guerras globais, houve uma crise ao modelo constitucional, necessitando de uma nova proposição diante dos eventos trazidos pelas Guerras Mundiais. Logo:

O Estado constitucional de direito desenvolve-se a partir do término da $2 a$. Guerra Mundial e se aprofunda no último quarto do século XX, tendo por característica central a subordinação da legalidade a uma Constituição rígida. A validade das leis já não depende apenas da forma de sua produção, mas também da compatibilidade de seu conteúdo com as normas constitucionais. Mais que isso: a Constituição não apenas impõe limites ao legislador e ao administrador, mas Ihes determina, também, deveres de atuação. A ciência do direito assume um papel crítico e indutivo da atuação dos Poderes Públicos e a jurisprudência passa a desempenhar novos papéis, dentre os quais se incluem a competência ampla para invalidar atos legislativos ou administrativos e para interpretar as normas jurídicas à luz da Constituição. Nesse ambiente se delinearam as múltiplas categorias do novo direito constitucional e da constitucionalização do Direito. (BARROSO, 2006, p. 16).

O novo constitucionalismo ou "neoconstitucionalismo" alvitra uma nova leitura do papel da Constituição e de sua formatação. "[...] Nesse paradigma em construção, incluem-se a reentronização dos valores na interpretação jurídica, com o reconhecimento de normatividade aos princípios [...] a formação de uma nova hermenêutica" (BARROSO, 2013, p. 31), baseada na dignidade da pessoa humana, na moral e nos direitos fundamentais. A função constitucional adquire mais uma responsabilidade, ou seja, a de interpretar os objetivos individuais e sociais, permitindo, ao mesmo tempo, que seja ela interpretada, inserida no contexto de cada momento. O neoconstitucionalismo, como marco basilar de sua estrutura jurídica,

[...] adota uma postura constitucionalista forte, na qual a constituição se faz efetiva como orientadora da política. As teses sobre hermenêutica constitucional, ampliação de catálogo de direitos fundamentais explícitos e implícitos e impregnação da constituição em praticamente todos os ramos do direito se tornam constantes. (BARBOSA; TEIXEIRA, 2017, p. 1.121).

Se antes dentro da hermenêutica clássica,no processo da interpretação, era possível encontrar com precisão a teleologianormativa, dos fatos e do intérprete, agora a Constituição deve ser compreendida como um texto aberto aos fatos sociais não antes vislumbrados pelo constituinte (BARROSO, 2013). Incluem-se também, nessa nova mentalidade constitucional, as posições morais e éticas da época e as posições majoritárias e contramajoritárias, mantendo a eficácia, a efetividade e a 
teleologia constitucional.

A intenção do atual paradigma do constitucionalismo é desenvolver a proteção de direitos e deveres da sua sociedade, não havendo impedimentos a uma tutela ou diálogo entre as constituições e demais sociedades do entorno. Uma Constituição deve estar aberta para interagir com outros sistemas e outras normas fundamentais. O neoconstitucionalismo não é reduzido a fronteiras da soberania, ou a barreiras ideológicas, formais, materiais, ele permite uma comunicação dentro de seus limites interpretativos e jurisdicionais para compor uma proteção. É possível, nesse ponto, almejar um pensamento constitucional que abrigue uma internacionalização ou uma governança global, uma colaboração entre Estados, estando esses entes soberanos integrados por suas constituições.

A intenção, em um primeiro momento, não é seguir os passos de integração da União Europeia, mas sim permitir que temas que disponham de uma tutela difusa e coletiva possam ser trabalhados em conjunto. A flexibilização de fronteiras é sobretudo do conhecimento, das técnicas, de informações que os países possuem; a intenção é permitir maior participação social e de grupos, para trazer novas percepções de proteção ambiental. A integração política e econômica não é interessante nesse momento, tendo em vista as divergências e a pluralidade política dos Estados.

A solidariedade e a governança global se manifestam no neoconstitucionalismo em virtude do pluralismo social que as constituições encontram em seu interior e por sua própria composição; por conseguinte, a mesma sistemática interna de compreender e assimilar a diversidade cultural e dos grupos encontra-se ressaltada em âmbito internacional. Direitos fundamentais, garantias individuais e coletivas não são mais compreendidas no novo modelo constitucional como restritas aos limites territoriais e jurisdicionais, algumas matérias e objetos jurídicos ultrapassam essas fronteiras; assim, a constituição deve estar preparada para lidar com a tutela desses bens em cooperação com outros diplomas jurídicos.

Afinal, o nível de bem-estar de que as sociedades desfrutam hoje em dia depende essencialmente, e em conjunto, das muitas maneiras pelas quais os Estados e outros atores internacionais interagem e cooperam na esfera internacional. Ao mesmo tempo em que torna o mundo mais interdependente, a necessidade de ações de cooperação torna-o mais monitorado se comparado ao passado, confirmando uma nova lógica de poder nas relações internacionais. (REl, 2018, p. 147). 
Essa compreensão cooperativa entre os Estados é necessária quando se observam objetos jurídicos como o meio ambiente, um direito difuso e coletivo essencial à vida humana e ao equilíbrio do ecossistema. O meio ambiente não apresenta fronteiras políticas e encontra-se vinculado a micros e macros ecossistemas. A atuação para dirimir e afastar a destruição ambiental, que possui múltiplas causas, precisa ser organizada em diversas frentes com participação social, econômica e governamental, compreendendo uma maior efetividade na tutela do meio (REI, 2018). Tem-se como exemplo a integração regional à proteção da Pan-Amazônia, em que a preocupação com a preservação desse espaço passa a não ser somente parte de um gerenciamento interno dos Estados, mas um pensamento coletivo cooperativo dos países.

Por meio das diversas constituições, existe uma proteção ou intenção normativa de tutelar a Amazônia em sua complexidade; como será avaliado a seguir, a proteção dada à Pan-Amazônia advém do modelo constitucional contemporâneo (neoconstitucionalismo), em que o paradigma comporta uma visão ampla às questões de direitos e garantias fundamentais.

\section{CONSTITUCIONALISMO E A PROTEÇÃO DA PAN-AMAZÔNIA}

O constitucionalismo contemporâneo encontra-se influenciado por outro fenômeno: a globalização, que trouxe a dissolução de fronteiras econômicas e das relações sociais, o compartilhamento mais dinâmico de informações, a agilidade no fornecimento e recebimento dos dados. O mundo globalizado trouxe consigo uma nova ordenação no espaço social, político, econômico e sobretudo ao Direito, pois redimensiona o alcance espacial de ação jurisdicional, situações que antes teriam um impacto localizado ou de perímetro regional dentro do Estado, ganharam visibilidade inter-regional ou intercontinental. Logo, o impacto de uma ação do direito reflete no local da causa, mas, sobretudo, repercute no mundo, implicando mudanças na ordem social interna de cada país (HELD;MCGREW, 2003).

Como conceito de globalização, tem-se:

Globalização diz respeito à multiplicidade de relações e interconexões entre Estados e sociedades, conformando o moderno sistema mundial. Focaliza o processo pelo qual os acontecimentos, decisões e atividades em uma parte domundo podem vir a ter consequências significativas para indivíduos e coletividade em lugares distantes do globo. (MCGROW, 1992, p. 23). 
A velocidade com que a sociedade evolui com a manifestação da globalização causa ao Direito externalidades positivas e negativas. O lado negativo é que o mundo jurídico e, nesse caso, o constitucional não consegue acompanhar as transformações e necessidades que ocorrem na sociedade. Essa falta de pareamento com a sociedade não ocorre somente nos dias de hoje, sempre foi percebida, mas o descompasso entre as normas e os avanços sociais aparentemente tomaram maiores distâncias. Por mais constante que sejam as interpretações, as decisões inovadoras e os encontros políticos e jurídicos, o Direito só consegue pacificar ou resolver parte das demandas, restando ainda outros fatos a serem definidos no mundo normativo, enquanto a humanidade prossegue sua caminhada de mudanças.

A parte positiva da globalização para o Direito são as possibilidades de interconexão com os demais ordenamentos jurídicos, e uma reciprocidade entre as constituições, o que possibilita uma atualização no espaço legal; os países ainda admitem a troca de informação, para atualizar a eficácia e a efetividade de suas leis. A globalização permite uma troca cultural e jurídica, consentindo que objetos que se limitariam à proteção soberana de um único Estado possam ter compartilhado a tutela do bem jurídico, logo as divisas tornam-se permeáveis a resoluções coletivas dos países, delegando parte das suas soberanias ou compartilhando atuações em consonância a uma governança internacional em determinados assuntos, dentre eles os ambientais.

O modo pelo qual se verifica essa abertura intergovernamental é pela via constitucional. A proteção do complexo florestal amazônico, dividido artificialmente entre as fronteiras dos países, é prova desse fenômeno constitucional globalizado. Mas a proteção internacional e a preocupação com o meio ambiente iniciam-se com Estocolmo em 1972, quando "[...] políticos, especialistas e autoridades de governo, representantes da sociedade civil e a ONU, se reuniram para discutir problemas ambientais na qual o meio ambiente foi colocado como tema principal [...]" (RAMOS, 2001, p. 203-204). O debate inaugurado na capital da Suécia permitiu novas contendas a respeito do meio ambiente, do desenvolvimento sustentável, das relações econômicas e sociais com o espaço ambiental.

Diante das discussões, a Floresta Amazônica ganha relevo no cenário internacional. Em 1978 tem-se a elaboração do Tratado de Cooperação Amazônica, 
com a pretensão normativa internacional de efetivar o desenvolvimento integral dos países possuidores de territórios amazônicos (MACHADO, 2016). Em posterior momento, em 1998, houve a emenda do tratado, em razão da criação da Organização do Tratado de Cooperação Amazônica (OTCA), pelo Protocolo de Caracas.

A assinatura foi feita principalmente por países compostos da PanAmazônia; após assinarem o acordo cooperativo internacional, passaram por transições constitucionais, evoluindo para o paradigma constitucional que se conhece atualmente. Conjuntamente com o Brasil, os demais países signatários do TCA foram influenciados pela Declaração de Estocolmo de 1972 e inseriramnos textos constitucionais a proteção ao meio ambiente (SOLA et al, 2007). Portanto, entender como suas leis fundamentais abarcaram e incluíram a proteção da Amazônia, o compartilhamento e integração da tutela se mostra necessário.

\begin{abstract}
O direito ao meio ambiente tem sua tradução não apenas como o direito a um meio ambiente de qualidade, mas também a condições dignas de vida, sobretudo em países em desenvolvimento. Seu caráter transgeracional é revolucionário e traz para o direito o desafio de adaptar-se para considerar o direito das coletividades futuras e assegurar para estas possibilidades de escolhas, o que só será possível se existirem alternativas válidas em relação ao uso e exploração dos recursos naturais [...] As demais constituições, posteriores à Declaração de Estocolmo de 1972, marco do direito ambiental, sofrem a influência dos princípios adotados por essa declaração internacional, dentre os quais o direito fundamental ao meio ambiente. Assim observar-se-á de forma paralela a nova abordagem do meio ambiente que trazem essas constituições. (SOLA et al, 2007, p. 10).
\end{abstract}

A Guiana, uma ex-colônia inglesa, em 1980 foi o primeiro país da região amazônica a adotar o modelo constitucional democrático. Passado longo interstício de tempo, mais precisamente em 2003, houve um processo de atualização de seu sistema político e econômico. A atual Constituição da Guiana possui em seu texto dispositivos de caráter genérico e aberto. Em seu preâmbulo, apresenta regras e princípios e assinala a proteção ao meio ambiente e à cultura, conforme afirmam Oliveira e Brito:

No capítulo que versa sobre os princípios e bases do sistema político, econômico e social, a Constituição impõe ao Estado o dever de zelar pela terra e pelo meio ambiente estabelecendo, ainda, o dever do cidadão de participar das atividades de proteção ambiental e de promoção da saúde pública, que depende da preservação do ar, da fertilidade do solo, dos recursos hídricos, da biodiversidade da fauna e flora e dos ecossistemas. 
(OLIVEIRA; BRITO, 2016, p. 175). ${ }^{3}$

Ainda em seu texto constitucional, a Guiana apresenta a proteção à cultura nacional, indicando proteção à diversidade de tradições e respeitando-as, e estabelece essa noção como um de seus princípios constitucionais ${ }^{4}$. A importância da qualidade do espaço ambiental (natural; artificial; cultural ou do trabalho), em que não ocasione prejuízo à saúde humana de plantas e animais, é encontrada na Constituição do país e pode ocasionar a interferência no direito de propriedade 5 .

Apesar de ser um dos mais antigos textos constitucionais adequados à tese neoconstitucionalista, a cooperação da Guiana ainda é pouco sentida. "No atual cenário de globalização de mercado, a formação de uma cultura comum de proteção e de promoção conjunta entre os povos da Amazônia Internacional permanece substancialmente enfraquecida" (OLIVEIRA; BRITO, 2016, p. 181). Por estar em um processo de crescimento, a Guiana se torna pouco expressiva em ações que promovam a proteção efetiva da Amazônia, mas não a impede de participar e buscar formas de cooperação e formação de uma eficaz tutela da floresta, concebida a partir do interesse constitucional.

O Suriname,outro país com território amazônico, ao se emancipar de sua excolônia, elabora em 1987, por meio de um referendo, sua Constituição. Igualmente como a Guiana, o Suriname inicia o texto de sua Constituição evidenciando objetivos como os desenvolvimentos culturais, econômicos e sociais, bem como a solidariedade internacional ${ }^{6}$ (CUNHA, 2016), e identifica uma abertura para a incorporação de técnicas jurídicas e culturais, jurisprudências e acordos que protejam a Amazônia.

Ao longo do texto constitucional do Suriname, observa-se a menção ao meio ambiente e sua tutela, no art. $6^{\circ 7}$, o qual está inserido no capítulo dos objetivos

\footnotetext{
${ }^{3} 25$. Every citizen has a duty to participate in activities designed to improve the environment and protect the health of the nation. [...]

36. In the interests of the present and future generations, the State will protect and make rational use of its land, mineral and water resources, as well as its fauna and flora, and will take all appropriate measures to conserve and improve the environment. (GUIANA, 1980).

${ }^{4} 35$. The State honours and respects the diverse cultural strains which enrich the society and will seek constantly to promote national appreciation of them at all levels and to develop out of them a socialist national culture for Guyana. (GUIANA, 1980).

5 ( $v$ ) in circumstances where it is reasonably necessary so to do because the property is in a dangerous state or injurious to the health of human beings, animals or plants. (GUIANA, 1980).

${ }^{6}$ determined to collaborate with one another and with all peoples of the world on the basis of freedom, equality, peaceful coexistence and international solidarity [...]. (SURINAME, 1987).

${ }^{7}$ Article 6: The social objectives of the State shall aim at:
} 
sociais e no art. $41^{8}$, referente ao capítulo do sistema econômico, no qual dispõe sobre as riquezas naturais. Por meio de uma intepretação sistemática e uma localização topográfica dos artigos da constituição, de certa forma ao que ocorreu em outros países, como o Brasil, pode-se entender que a proteção do meio ambiente no Suriname ocorre vinculada a uma perspectiva do desenvolvimento econômico, com o uso dos recursos naturais, culturais e artificiais, de forma equilibrada e sustentável.

O Brasil, que no final do seu processo de redemocratização promulga a Constituição Federal de 1988, no qual o meio ambiente é inserido como um direito fundamental, e que o princípio do Meio Ambiente Ecologicamente Equilibrado é Direito Fundamental de todos, ou seja, é um compromisso e um norte ao Estado (REZENDE, 2016). A Constituição brasileira dispõe a tutela ambiental entre todos seus entes federativos, repartindo a matéria ambiental às competências comuns, concorrentes, exclusivas e privadas. Destaca a participação jurídica e política de atores sociais, sejam grupos, sejam indivíduos, para que possam alcançar a preservação do ambiente. Outrossim, a Constituição Federal estabelece uma relação com suas normas internas, com organismos e políticas internacionais, assim como outros estados vizinhos para proteger o meio ambiente.

A Constituição Federal de 1988 designa capítulo específico para o meio ambiente: o art. 225, que dispõe ao longo de seus parágrafos e incisos sobre esse bem jurídico, citando explicitamente a necessidade da proteção da Floresta Amazônica brasileira em seu parágrafo $4^{\circ 9}$. Igualmente, embora exista designação constitucional própria ao meio ambiente, ela ao longo do seu texto consagra a proteção ao meio ambiente, em suas vertentes cultural, artificial, natural e do

a. The identification of the potentialities for development of the own natural environment and the enlarging of the capacities to ever more expand those potentialities; [...]

c. Guaranteeing a government policy aimed at raising the standard of living and of well-being of the society, based upon social justice, the integral and balanced development of State and society; [...]

g. Creating and improving the conditions necessary for the protection of nature and for the preservation of the ecological balance. (SURINAME, 1987).

${ }^{8}$ Article 41: Natural riches and resources are property of the nation and shall be used to promote economic, social and cultural development. The nation has the inalienable right to take complete possession of its natural resources in order to utilize them to the benefit of the economic, social and cultural development of Suriname. (SURINAME, 1987).

${ }^{9}$ Art. 225. Todos têm direito ao meio ambiente ecologicamente equilibrado, bem de uso comum do povo e essencial à sadia qualidade de vida, impondo-se ao Poder Público e à coletividade o dever de defendê-lo e preservá-lo para as presentes e futuras gerações. [...]

$\S 4^{\circ}$ A Floresta Amazônica brasileira, a Mata Atlântica, a Serra do Mar, o Pantanal Mato-Grossense e a Zona Costeira são patrimônio nacional, e sua utilização far-se-á, na forma da lei, dentro de condições que assegurem a preservação do meio ambiente, inclusive quanto ao uso dos recursos naturais. (BRASIL, 1988). 
trabalho, permitindo a defesa desses espaços de forma sistemática e teleológica (MACHADO, 2017).

Assim, a vigente Constituição brasileira instalou em seu texto o meio ambiente como norma fundamental, direito de terceira geração, difuso e coletivo.Permitiu às pessoas o seu uso de forma comum sem distinção e instituiu o dever de tutela ambiental para as futuras gerações, impondo o dever de preservação do meio ambiente para as pessoas e concomitantemente a todos os entes federativos. A ideia é que todas as ações de proteção estejam integradas, sejam solidárias e multidisciplinares, entre sociedade, setores econômicos e governos, para além de objetivos políticos, econômicos e ideológicos (KALIL; FERREIRA, 2017).

Em 1991, a Colômbia, no mesmo sentido, promulga a sua Constituição, seguindo as mudanças e modernizações jurídicas que ocorriam nos países vizinhos. O país "[...] foi um dos primeiros países da América Latina a apresentar normas específicas sobre a proteção dos recursos naturais e do meio ambiente. Apesar desse pioneirismo, não se encontram muitas referências que tratam exclusivamente sobre a proteção da Amazônia" (RAMOS, 2016, p. 97-98).

A primeira referência ao meio ambiente é estabelecida no art. 67 , dentro do capítulo intitulado De losderechossociales, económicos y culturales. Ao tratar da educação, a Lei Fundamental explicita a necessidade de uma educação voltada para a compreensão dos direitos humanos, da democracia, a paz e o espaço ambiental. Posteriormente, segue a lógica constitucional dos países vizinhos e, dessa forma, no capítulo três, discorre sobre a proteção ambiental e os direitos coletivos. Assim, principalmente os arts. 79 e $82^{10}$ estabelecem uma proteção direta

\footnotetext{
${ }^{10}$ Artículo 79. Todas las personas tienen derecho a gozar de un ambiente sano. La ley garantizará la participación de la comunidad en las decisiones que puedan afectarlo.

Es deber del Estado proteger la diversidad e integridad del ambiente, conservar las áreas de especial importancia ecológica y fomentar la educación para el logro de estos fines.

Artículo 80. El Estado planificará el manejo y aprovechamiento de los recursos naturales, para garantizar su desarrollo sostenible, su conservación, restauración o sustitución.

Además, deberá prevenir y controlar los factores de deterioro ambiental, imponer las sanciones legales y exigir la reparación de los daños causados.

Así mismo, cooperará con otras naciones en la protección de los ecosistemas situados en las zonas fronterizas.

Artículo 81. Queda prohibida la fabricación, importación, posesión y uso de armas químicas, biológicas y nucleares, así como la introducción al territorio nacional de residuos nucleares y desechos tóxicos.

El Estado regulará el ingreso al país y la salida de él de los recursos genéticos, y su utilización, de acuerdo con el interés nacional.

Artículo 82. Es deber del Estado velar por la protección de la integridad del espacio público y por su
} 
ou sistemática do ambiente e seus recursos (COLÔMBIA, 1991).

Contudo, apesar de caminhar no mesmo sentido constitucional de outros países da América Latina, de endossar a importância do meio ambiente e de destacar em um capítulo próprio o tema, a Colômbia manifesta um acanhamento no trato jurídico desse objeto. Não há ao longo do texto constitucional colombiano desenvolvimento à proteção ambiental ou garantias de defesa da Floresta Amazônica. Embora contenha um capítulo em separado para trazer uma abordagem inovadora e ampla, é tímido; os artigos constitucionais não aprofundam princípios, normas gerais e específicas, somente colocando o dever de sua tutela pelo Estado e observância deste pela sociedade.

O Peru segue o mesmo parâmetro dos demais países supracitados; após a II Guerra Mundial, o país adotou uma Constituição em 1993 com normas programáticas, a inserção dos direitos fundamentais ${ }^{11}$, aberta ao diálogo social. Dessa forma, o texto constitucional vigente trouxe uma consciência ambiental progressista, com dispositivos de proteção ambiental ligados especialmente à região da Amazônia peruana, às comunidades nativas e recursos naturais ali existentes (OLIVEIRA; SAMPAIO, 2016).

Para compor a tutela ambiental, do mesmo modo que o Brasil, a Constituição peruana atribuiu ao meio ambiente um capítulo - Del ambiente y los recursos naturales (PERU, 1993) -, que vai dos arts. 66 ao $69^{12}$. No texto constitucional, o Peru compreende especialmente o meio ambiente natural, propondo uma política ambiental, e salvaguarda os recursos naturais, a diversidade biológica e áreas naturais, em especial a Amazônia, como já destacado. Observa-se que, diferentemente da Constituição brasileira, o texto peruano não desenvolve uma

destinación al uso común, el cual prevalece sobre el interés particular.

Las entidades públicas participarán en la plusvalía que genere su acción urbanística y regularán la utilización del suelo y del espacio aéreo urbano en defensa del interés común. (COLÔMBIA, 1991).

${ }^{11}$ Artículo 2.- Derechos fundamentales de la persona

Toda persona tiene derecho: [...] 22. A la paz, a la tranquilidad, al disfrute del tiempo libre y al descanso, así como a gozar de un ambiente equilibrado y adecuado al desarrollo de su vida. (PERU, 1993).

${ }^{12}$ Artículo 66.- Recursos Naturales: Los recursos naturales, renovables y no renovables, son patrimonio de la Nación. El Estado es soberano en su aprovechamiento.

Por ley orgánica se fijan las condiciones de su utilización y de su otorgamiento a particulares. La concesión otorga a su titular un derecho real, sujeto a dicha norma legal.

Artículo 67.- Política Ambiental: El Estado determina la política nacional del ambiente. Promueve el uso sostenible de sus recursos naturales.

Artículo 68.- Conservación de la diversidad biológica y áreas naturales protegidas: El Estado está obligado a promover la conservación de la diversidad biológica y de las áreas naturales protegidas.

Artículo 69.- Desarrollo de la Amazonía: El Estado promueve el desarrollo sostenible de la Amazonía con una legislación adecuada. (PERU, 1993). 
proteção sistemática, não reconhece outras divisões do meio ambiente, desprotegendo, direta ou indiretamente, os demais tipos de espaços ambientais que não seja o natural.

Inserido no texto constitucional do Peru, encontra-se a referência do meio ambiente quanto a sua manutenção pelos governos regionais dentro de uma perspectiva econômica (PERU, 1993). A proposta peruana é de que governos locais também visualizem e pratiquem a proteção e o uso sustentável, não impedindo que as diferenças sociais e culturais de cada região sejam esquecidas; é uma forma de melhor integrar a preservação do espaço ambiental.

Em 1999 a Venezuela estabelece em sua Constituição, precisamente em seu preâmbulo e ao longo de seu texto, o pluralismo cultural, a proteção ambiental, a defesa dos povos originários e a integração dos países latino-americanos. Em sua teoria constitucional (aqui, não deixando de observar o campo dos fatos, não sendo, contudo, objeto desta pesquisa), a Venezuela propõe maior participação social em temas que a eles se referem, sobretudo os ambientais. Assim, a sociedade pode participar de forma mais ativa da vida política e das tomadas de decisões dos governantes.

O art. $15^{13}$ da Constituição venezuelana, incluso no capítulo que trata da divisão política e geográfica do país, explicita a preservação ambiental em consonância com as especificidades locais, regionais, culturais e econômicas. Seguindo a composição normativa constitucional, o art. 87 estabelece a manutenção da qualidade e saúde do meio ambiente do trabalho. A educação ambiental está presente na preocupação normativa fundamental do Estado, em seu art. 107. Esse dispositivo põe a educação ambiental como dever em todo o sistema educacional vigente, bem como uma educação ambiental disponibilizada aos cidadãos e em instituições públicas e privadas ${ }^{14}$, e ressalta a importância ambiental para a vida social (VENEZUELA, 1999).

\footnotetext{
${ }^{13}$ Artículo 15. El Estado tiene la responsabilidad de establecer una política integral en los espacios fronterizos terrestres, insulares y marítimos, preservando la integridad territorial, la soberanía, la seguridad, la defensa, la identidad nacional, la diversidad y el ambiente, de acuerdo con el desarrollo cultural, económico, social y la integración. Atendiendo la naturaleza propia de cada región fronteriza a través de asignaciones económicas especiales, una ley orgánica de fronteras determinará las obligaciones y objetivos de estaresponsabilidad. (VENEZUELA, 1999).

14 Artículo 107. La educación ambiental es obligatoria en los niveles y modalidades del sistema educativo, así como también en la educación ciudadana no formal. Es de obligatorio cumplimiento en las instituciones públicas y privadas, hasta el ciclo diversificado, la enseñanza de la lengua castellana, la historia y la geografía de Venezuela, así como los principios del ideariobolivariano. (VENEZUELA, 1999).
} 
Nesse sentido, "também o artigo 110, apesar de não relacionar explicitamente as matérias de ciências e tecnologia às questões de proteção e desenvolvimento ambiental, merece ser citado, pois aquelas são instrumentos fundamentais para estes fins" (COSTA, 2016, p. 297). A proposição do texto venezuelano é possibilitar a proteção ao meio ambiente sem eliminar 0 desenvolvimento social e econômico do país, como demonstrado nos art. 112 e 113 da Constituição. Por último, análogo ao constitucionalismo brasileiro, a Venezuela separa um capítulo exclusivo para o Direito Ambiental do art. 127 ao art. $129^{15}$.

No tocante aos artigos citados, há a preocupação de proteger os recursos ambientais para gerações presentes e futuras, e segue os princípios da proteção do Protocolo de Estocolmo em 1972, compreendendo uma gama de objetos a serem tutelados juridicamente além dos bens naturais. Institui em âmbito constitucional o estudo de impactos ambientais social e cultural; tem o cuidado de preservar o ambiente contra elementos tóxicos e perigosos, cabendo à Venezuela a preservação conforme especificidades regionais, sociais e geográficas em conjunto com a sociedade. Por fim, direciona o diálogo internacional com outros países e regiões para melhor estruturar a defesa do meio ambiental.

Tem-se em 2008 a Constituição do Equador, que em seu preâmbulo já

\footnotetext{
${ }^{15}$ Artículo 127. Es un derecho y un deber de cada generación proteger y mantener el ambiente en beneficio de sí misma y del mundo futuro. Toda persona tiene derecho individual y colectivamente a disfrutar de una vida y de un ambiente seguro, sano y ecológicamente equilibrado. El Estado protegerá el ambiente, la diversidad biológica, genética, los procesos ecológicos, los parques nacionales y monumentos naturales y demás áreas de especial importancia ecológica. El genoma de los seres vivos no podrá ser patentado, y la ley que se refiera a los principios bioéticos regulará la materia.

Es una obligación fundamental del Estado, con la activa participación de la sociedad, garantizar que la población se desenvuelva en un ambiente libre de contaminación, en donde el aire, el agua, los suelos, las costas, el clima, la capa de ozono, las especies vivas, sean especialmente protegidos, de conformidad con la ley.

Artículo 128. El Estado desarrollará una política de ordenación del territorio atendiendo a las realidades ecológicas, geográficas, poblacionales, sociales, culturales, económicas, políticas, de acuerdo con las premisas del desarrollo sustentable, que incluya la información, consulta y participación ciudadana. Una ley orgánica desarrollará los principios y criterios para este ordenamiento.

Artículo 129. Todas las actividades susceptibles de generar daños a los ecosistemas deben ser previamente acompañadas de estudios de impacto ambiental y socio cultural. El Estado impedirá la entrada al país de desechos tóxicos y peligrosos, así como la fabricación y uso de armas nucleares, químicas y biológicas. Una ley especial regulará el uso, manejo, transporte y almacenamiento de las sustancias tóxicas y peligrosas.

En los contratos que la República celebre con personas naturales o jurídicas, nacionales o extranjeras, o en los permisos que se otorguen, que involucren los recursos naturales, se considerará incluida aun cuando no estuviera expresa, la obligación de conservar el equilibrio ecológico, de permitir el acceso a la tecnología y la transferencia de la misma en condiciones mutuamente convenidas y de restablecer el ambiente a su estado natural si éste resultara alterado, en los términos que fije la ley. (VENEZUELA, 1999).
} 
invoca o meio ambiente na figura do que eles chamam de Pacha Mama (ou Pachamama $)^{16}$, figura importante para os povos originários da região dos Andes, mas também para a sociedade atual como forma de retomada paradigmática. $O$ termo produz não só uma dimensão de proteção ao meio ambiente por intermédio da figura de uma divindade andina, mas também engloba a sociedade nesse meio ambiente, ou seja, os indivíduos constroem espaços ambientais (como os artificiais, os digitais), mas também são parte do meio ambiente.

O termo pachamama é formado pelos vocábulos 'pacha' que significa universo, mundo, tempo, lugar, e 'mama' traduzido como mãe. De acordo com vestígios que restaram, a Pachamama é um mito andino que se refere ao 'tempo' vinculado à terra. Segundo tal mito, é o tempo que cura os males, o tempo que extingue as alegrias mais intensas, o tempo que estabelece as estações e fecunda a terra dá e absorve a vida dos seres no universo. O significado 'tempo' advém da língua Kolla-suyu, falada pelos aborígenes que habitavam a zona dos Andes durante o processo de colonização. No transcorrer dos anos, com o predomínio de outras raças e de modificações na linguagem, pachamama passou a significar 'terra' merecedora do culto. (TOLENTINO; OLIVEIRA, 2015, p. 315-316, grifo do autor).

O texto constitucional equatoriano insere elemento novo: a referência aos povos originários. Esses povos habitavam a região desde antes da colonização da América e são detentores de cultura, tradições, histórias, ciências, religião; e sobretudo têm uma conexão com a natureza própria, agora reverenciada na Constituição. A defesa do meio ambiente passa por uma preocupação social, auxiliada pela noção de antigas culturas, para a preservação do meio, em que há participação coletiva.

O art. $1^{\circ 17}$ da Constituição equatoriana destaca a importância dos recursos naturais, pertencendo ao seu patrimônio inalienável, irrenunciável e imprescritível. No art. $10^{18}$, houve ampliação da concepção do meio ambiente, deixando de ser objeto destinado ao uso, gozo e disposição humana, para ser sujeito de direitos elencados na Constituição. “O 'giro biocêntrico' a que se refere [...] representa uma quebra de paradigmas muito importante para o contexto pan-amazônico, na medida em que, muitas vezes, os demais países da bacia têm encontrado dificuldades em

\footnotetext{
${ }^{16}$ CELEBRANDO a la naturaleza, la Pacha Mama, de la que somos parte y que es vital para nuestra existencia [...]. (EQUADOR, 2008).

${ }^{17}$ Art. 1.- [...] Los recursos naturales no renovables del territorio del Estado pertenecen a su patrimonio inalienable, irrenunciable e imprescriptible. (EQUADOR, 2008).

18 Art. 10.- [...] La naturaleza será sujeto de aquellos derechos que le reconozca la Constitución. (EQUADOR, 2008).
} 
lidar com algumas questões" (BIZAWU; CUNHA, 2016, p. 132).

A qualidade do meio ambiente foi reservada à tutela constitucional nos art. 14 e 15. $\mathrm{O}$ art. 27 dedica-se à educação ambiental, em conjunto com uma visão holística do mundo e dos direitos humanos para melhor atender aos preceitos ambientais. $\mathrm{O}$ art. 74 dispõe sobre o uso dos recursos ambientais promotores da vida humana. Nas disposições do art. 83, indica-se a previsão de um uso sustentável e racional dos recursos encontrados no meio ambiente (EQUADOR, 2008). O Equador, ao promover a mudança constitucional, permitiu integrar o Estado, sua máquina pública, a sociedade, os povos ancestrais e os países do entorno para o amparo ambiental, dando finalidade harmônica a esses atores sem prejuízo ao meio ambiente.

Assim como outros países, a Constituição do Equador destinou ao meio ambiente o capítulo segundo - Biodiversidad y recursos naturales, abarcando do art. 395 ao art. 415. Entre o extenso rol de artigos dispondo sobre questões ambientais, o art. $395^{19}$ expõe quatro princípios ambientais, dentre eles: o dever de agir do Estado para garantir a sustentabilidade, o equilíbrio, a diversidade cultural, a biodiversidade e ecossistemas; o dever de gestão ambiental, em todo o âmbito estatal; a garantia de participação ativa e permanente dos indivíduos afetados pelos impactos ambientais; e o princípio da presunção pró-ambiente, em que, havendo dúvidas sobre possíveis lesões ao meio ambiente, se aplicará a lei no sentido mais favorável ao meio ambiente.

Por fim, em relação à preservação da Floresta Amazônica, foi expressa no art. $250^{20}$ a importância dela para a manutenção do equilíbrio ambiental no mundo,

\footnotetext{
${ }^{19}$ Art. 395.- La Constitución reconoce los siguientes principios ambientales:

1. El Estado garantizará un modelo sustentable de desarrollo, ambientalmente equilibrado y respetuoso de la diversidad cultural, que conserve la biodiversidad y la capacidad de regeneración natural de los ecosistemas, y asegure la satisfacción de las necesidades de las generaciones presentes y futuras.

2. Las políticas de gestión ambiental se aplicarán de manera transversal y serán de obligatorio cumplimiento por parte del Estado en todos sus niveles y por todas las personas naturales o jurídicas en el territorio nacional.

3. El Estado garantizará la participación activa y permanente de las personas, comunidades, pueblos y nacionalidades afectadas, en la planificación, ejecución y control de toda actividad que genere impactos ambientales.

4. En caso de duda sobre el alcance de las disposiciones legales em materia ambiental, éstas se aplicarán en el sentido más favorable a la protección de la naturaleza. (EQUADOR, 2008).

${ }^{20}$ Art. 250.- El territorio de las provincias amazónicas forma parte de un ecosistema necesario para el equilibrio ambiental del planeta. Este territorio constituirá una circunscripción territorial especial para la que existirá una planificación integral recogida en una ley que incluirá aspectos sociales, económicos, ambientales y culturales, con un ordenamiento territorial que garantice la conservación y protección de sus ecosistemas y el principio del sumak kawsay. (EQUADOR, 2008).
} 
reconhecendo a necessidade de integração territorial especial para a conservação e proteção em aspectos sociais, econômicos e ambientais que a promoção de uma salvaguarda possa destinar, entre os Estados participantes da Pan-Amazônia. Já o art. $259^{21}$ garante que o Estado central, em conjunto com os governos, desenvolverá políticas sustentáveis dentro do ecossistema amazônico (EQUADOR, 2008).

Em 2009 a Bolívia promulga sua Constituição; é um dos outros países a invocar desde seu preâmbulo a figura da pachamama, ou como trazem em seu texto Madre Tierra22. A concepção da pluralidade de pessoas, grupos, coisas e culturas está posta, a fim de evidenciar a importância destes para a construção do país. Por conseguinte, em seu art. $9^{\circ 23}$ prevê o meio ambiente como uma tutela estatal, no intuito de promover o (re)aproveitamento dos recursos naturais, a conservação e a produtividade (KOKKE, 2016). Em seguida, no art. $33^{24}$, no capítulo de direitos sociais e econômicos, indica que o meio ambiente ultrapassa as barreiras do direito de titularidade exclusiva aos humanos e ao seu uso; assim, "[...] não somente dos seres humanos em suas gerações presentes e futuras, mas também como direito de todos os seres vivos ao desenvolvimento regular e permanente (KOKKE, 2016, p. 23).

A Constituição da Bolívia prevê educação ambiental em seu art. 80, fortalecendo a unidade, identidade, a noção da essencialidade de preservação do meio ambiente. Ao longo do texto da Constituição, há uma série de previsões assemelhadas ao que foi posto por outras constituições de outros países, como a saúde ambiental, sustentabilidade econômica dos recursos naturais e condições salubres do ambiente de trabalho.

\footnotetext{
${ }^{21}$ Art. 259.- Con la finalidad de precautelar la biodiversidad del ecosistema amazónico, el Estado central y los gobiernos autónomos descentralizados adoptarán políticas de desarrollo sustentable que, adicionalmente, compensen las inequidades de su desarrollo y consoliden la soberanía. (EQUADOR, 2008).

22 En tiempos inmemoriales se erigieron montañas, se desplazaron ríos, se formaron lagos. Nuestra amazonia, nuestro chaco, nuestro altiplano y nuestros llanos y valles se cubrieron de verdores y flores. Poblamos esta sagrada Madre Tierra con rostros diferentes, y comprendimos desde entonces la pluralidad vigente de todas las cosas y nuestra diversidad como seres y culturas. Así conformamos nuestros pueblos, y jamás comprendimos el racismo hasta que lo sufrimos desde los funestos tiempos de la colonia. (BOLÍVIA, 2009).

${ }^{23}$ Artículo 9. [...] 6. Promover y garantizar el aprovechamiento responsable y planificado de los recursos naturales, e impulsar su industrialización, a través del desarrollo y del fortalecimiento de la base productiva en sus diferentes dimensiones y niveles, así como la conservación del medio ambiente, para el bienestar de las generaciones actuales y futuras. (BOLíVIA, 2009).

${ }^{24}$ Artículo 33. Las personas tienen derecho a un medio ambiente saludable, protegido y equilibrado. El ejercicio de este derecho debe permitir a los individuos y colectividades de las presentes y futuras generaciones, además de otros seres vivos, desarrollarse de manera normal y permanente. (BOLÍVIA, 2009).
} 
Igualmente, a Bolívia coloca o meio ambiente em capítulo próprio junto a demais temas correlatos, trabalhando com questões ambientais gerais, até os recursos naturais, disponíveis entre o art. 342 e o art. 358 da lei fundamental. Assim, o artigo dedica-se a descrever a necessidade de uma defesa conjunta do Estado e da sociedade na proteção ambiental, seu uso sustentável e formas de aproveitamento do material usado ou reutilizado (BOLÍVIA, 2009). Outro destaque importante é o capítulo oitavo da Constituição boliviana, que dispõe sobre a Amazônia entre o art. 390 e o art. 392, delimitando a administração, gestão e preservação da floresta, a integração com os demais países e a sustentabilidade do uso dos bens ambientais amazônicos, como manutenção para as presentes e futuras gerações (BOLÍVIA, 2009).

O objetivo é garantir a preservação do meio natural e de outros tipos, de forma que o uso seja consciente, a participação nas tomadas de decisões de forma democrática e transparente cujo maior beneficiário não seja somente a sociedade ou outros grupos de poder, mas o próprio meio (BOLÍVIA, 2009).

Todo o estudo de como as constituições dos países da Pan-Amazônia construíram uma proteção ambiental mostra como o paradigma neoconstitucional abriga e abarca novos direitos fundamentais. Percebe-se que houve avanços no modelo constitucional latino, após a Conferência de Estocolmo em 1972, e o desenvolvimento de uma pesquisa sobre o meio ambiente e os recursos naturais, a redemocratização de países que implementaram em seus textos constitucionais uma visão ou exigência de proteger o meio ambiente, educar, sustentabilizar, sensibilizar e punir em matéria ambiental.

O novo constitucionalismo latino é o paradigma vigente, é orgânico por ser mais semelhante com as características sociais e adaptável, mesmo que de forma lenta, a essas questões impressas na sociedade, o que não ocorria no modelo constitucional superado. O neoconstitucionalismo permite aprofundar e estabelecer o diálogo com seus cidadãos. Assim, observando aquilo que anseiam e desejam; as interações entre outras fontes constitucionais dos países que fazem parte da região amazônica; e a governança ambiental no sentido de gerir e tutelar o bem ambiental, não somente para seu povo, mas para diversas outras populações e gerações.

Entende-se assim que as constituições dialogam, permitem contato com outras tradições e constituições. Dessa forma, os povos originários, vistos inicialmente como sujeitos legatários de uma proteção especial, podem contribuir 
para proteger a Floresta Amazônica, pois detêm uma cultura, uma percepção e relacionamento diferente com o meio ambiente. $O$ passo dado pelas diversas leis fundamentais aqui expostas auxilia a compreensão e o destaque da participação desses povos, a sua contribuição transdisciplinar a ser absorvida e assimilada pela cultura jurídica.

O novo constitucionalismo toma importância por permitir a troca entre a tradição jurídica e dos povos originários, porque a primeira pode se utilizar da segunda para construir uma sensibilização, sendo fielmente cumpridos os ditames constitucionais pelo Estado, pela sociedade e por quem possui algum interesse. $\mathrm{O}$ modelo constitucional latino atual é importante para conectar a tradição jurídica positiva ao movimento cultural de povos, com objetivo de proteger e melhor comporse com o meio ambiente, como será estudado a seguir.

\section{O PARADIGMA DOS POVOS ORIGINÁRIOS PARA A CONSTRUÇÃO NEOCONSTITUCIONAL DE PROTEÇÃO DA AMAZÔNIA}

O antigo desenho constitucional da América Latina "[...] é marcado por acordos políticos entre conservadores e liberais, elites que tinham como propósito manter a mesma estrutura de dominação colonial sem qualquer modificação estrutural na sociedade [...]" (BARBOSA; TEIXEIRA, 2017, p. 1.119). Não houve avanços ou inovações para a sociedade em termos de direitos no momento de introjeção do modelo constitucional; mantiveram-se as estruturas sociais, as desigualdades, não obtiveram uma integração cultural e dos cidadãos, as classes dominantes continuaram a exercer e a distribuir suas influências por esse período.

Contudo, o redesenho constitucional, sobretudo a partir da redemocratização dos países, e da experiência violenta das guerras e os parâmetros dos países latinos abraçaram uma nova agenda de direitos e garantias fundamentais. $O$ velho modelo de distanciamento e separação social foi substituído por participação popular no debate democrático, político e social. Logo, as novas constituições produziram marcos políticos, jurídicos e institucionais originais em relação ao constitucionalismo clássico (AVRITZER, 2017).

O novo constitucionalismo latino-americano necessitou romper com o modelo anterior, por uma questão social, ética, étnica e cultural: o padrão de sociedade europeia ou norte-americano não reflete a pluralidade cultural da região 
sul-americana. Isso se deve pelo grande número de povos originários que habitavam o local antes mesmo da chegada dos colonos, e a distinção cultural de cada grupo.

A importância dada pelos textos constitucionais não é equívoca; ela traz, mesmo que de forma tímida, uma relevância às tradições desses povos, e como elas podem ou devem ser incluídas no sistema jurídico e ético-normativo dos Estados. Dessa forma, para os países que integram a região amazônica, integrar a perspectiva de proteção ambiental entre eles de forma jurídica e entre as diferentes culturas é um movimento transdisciplinar e decolonial ${ }^{25}$, um objetivo aceito constitucionalmente e que deve ser cumprido. Assim:

Os impasses e as insuficiências do atual paradigma da ciência jurídica tradicional entreabrem, lenta e constantemente, o horizonte para as mudanças e a construção de novos paradigmas, direcionados para uma perspectiva pluralista, flexível e interdisciplinar. A teoria jurídica formalista, instrumental $e$ individualista vem sendo profundamente questionada por meio de seus conceitos, de suas fontes e de seus institutos diante das múltiplas transformações tecnocientíficas, das práticas de vida diferenciadas, da complexidade crescente de bens valorados e de novas necessidades básicas, bem como da emergência de novos atores sociais, portadores de novas subjetividades (individuais e coletivas). (WOLKMER, 2012, p. 17).

Portanto, cabe à normatividade, à dogmática, aos princípios e aos agentes estatais e à própria sociedade determinarem condições de atualização de seu ordenamento interno e coletivo (acordos internacionais) que verifiquem a inserção da transdisciplinaridade em suas bases jus-éticas, pois

a construção discursiva em torno do referencial da cidadania representa um eficiente meio para permitir a convivência entre diferentes, já que permite a separação do âmbito privado (onde as pessoas podem ser diferentes em suas crenças, convicções, etc.) do âmbito público (onde as pessoas devem ser iguais, já que cidadãos). Nesse sentido, o conceito de cidadania surge como forma de alargar os laços de pertinência ao grupo. Assim, o estabelecimento da cidadania permite transcender as diferenças, criando um estatuto homogeneizador fundado não mais em uma identidade cultural, mas no reconhecimento jurídico de uma igualdade formal.(BARBOSA; TEIXEIRA, 2017, p. 1.123-1.124).

Compreende-se que o objetivo de inserir as comunidades originárias em

\footnotetext{
25 Entende-se, para essa pesquisa, por decolonialidade o movimento surgido, principalmente, de países latino-americanos que estudam a compreensão da modernidade no contexto da teoria crítica, aplicada a estudos étnicos, culturais, religiosos e plurissociais. A decolonialidade critica a visão eurocêntrica e norte-americana, os modelos asociais e, neste caso, os jurídicos-éticos dessas tradições, discutindo um pensamento próprio de leis, mas que, sobretudo, possua integração cultural com povos originários e afrodescendentes. (MIGNOLO, 2011).
} 
uma democracia neoconstitucional é enxergar a pluralidade que existe no mundo, e partindo dessa concepção o Direito deve se atualizar. Em matéria ambiental, a cultura desses grupos no trato com o meio ambiente vem para auxiliar como os países podem lidar com a proteção ambiental, extraindo para o ambiente jurídico a forma como as comunidades originárias lidam, interagem e preservam o local que habitam.

Integrar o saber tradicional ${ }^{26}$ ao direito posto é auxílio para a visão protetiva da Floresta Amazônica, "[...] o crisol onde diferentes culturas e saberes se hibridam para forjar novas ideias, novas racionalidades e novos mundos de vida" (LEFF, 2012, p. 124). Aqui, não se fala exclusivamente em uma visão geo-cosmológica, semelhante ao que se tem nos países de região andina, o Constitucionalismo Andino, "[...] uma cosmovisão alternativa, derivada da valorização do mundo indígena e da refundação das instituições políticas, que reconhecem as necessidades históricas de culturas originárias encobertas de identidades radicalmente negadas ante sua própria história" (WOLKMER, 2014, p. 72). Mas se verifica a possibilidade de trazer as práticas harmônicas ou sustentáveis desses povos na conservação florestal.

\begin{abstract}
Nesse sentido, aprender a complexidade ambiental, implica um processo de 'desconstrução' do pensado para se pensar o ainda não pensado, para se desentranhar o mais estranhável de nossos saberes e para dar curso ao inédito, arriscando-se a desmanchar nossas últimas certezas e a questionar o edifício da ciência. (LEFF, 2010, p. 196).
\end{abstract}

Observar práticas tradicionais, ou a relação simbiôntica das comunidades tradicionais, não é destruir todo o conteúdo jurídico já instaurado, mas permitir que ele se adeque e se atualize para as questões sociais de cada país. Portanto, "o saber ambiental é um saber sobre esse campo externalizado pela racionalidade econômica, científica e tecnológica da modernidade; mas por sua vez conota os saberes marginalizados e subjugados pela centralidade do logos científico" (LEFF,

\footnotetext{
${ }^{26}$ Entende-se por saber ou conhecimento tradicional: [...] o conjunto dos traços distintivos espirituais e materiais, intelectuais e afectivos que caracterizam uma sociedade ou um grupo social e que abrange, além das artes e das letras, os modos de vida, as formas de viver em comunidade, os sistemas de valores, as tradições e as crenças (UNESCO, 2001).

Em mesmo sentido, [...] o conhecimento, além de estar ligado a um savoir-faire, como um ter jeito, relaciona-se com uma rede conceitual de conhecimentos espaciais e ambientais tão ou mais essenciais que na cultura manual e técnica. Tudo isso surge de um processo que pressupõe um sujeito cognitivo em constante interação entre o trabalho mental e manual, e entre este e seu entorno (ALLUT, 2001, p. 113).
} 
2010, p. 160).

A atual composição constitucional dos países latinos fez emergir a intencionalidade de conjugar racionalidade e cientificidade, com os saberes tradicionais e culturais dos povos dentro e fora de suas fronteiras. A troca de conhecimento permite expandir o capital protetivo, além de conservar práticas tradicionais, respeitá-las e tutelá-las dentro do organismo normativo presente nos Estados e acordos firmados entre eles. Assim:

\begin{abstract}
A identidade na perspectiva da complexidade ambiental implica dar um salto fora da lógica formal, para pensar um mundo conformado por uma diversidade de identidades que constituem formas diferenciadas do ser individual e do ser coletivo dos povos. Nesse sentido, o saber e pensar a partir da identidade resiste e enfrenta a imposição de um pensar externo sobre seu próprio ser, a partir do conhecimento científico e das etnociências como apropriação do ser dos povos (de seus saberes), a partir da lógica da globalização ecológico-econômica. (LEFF, 2015, p. 434).
\end{abstract}

Como resultado, o neoconstitucionalismo reconstrói o paradigma clássico vigente promovendo diálogo, integração e hibridação, à luz dos múltiplos saberes, dos novos conhecimentos políticos e jurídicos (LEFF, 2010). A mudança que se alcança com essa nova formulação produz efeitos não somente em âmbito constitucional ou entre nações, permite que o sistema interno também se encontre sob essa nova perspectiva, ou seja, direito público, privado, fundamentais, individuais e coletivos passam a integrar a experiência das comunidades tradicionais. "A inter e a transdisciplinaridade que demanda o saber ambiental não é a busca de um paradigma globalizante do conhecimento [...] o saber ambiental está num processo de construção" (LEFF, 2010, p. 163).

O neoconstitucionalismo latino é capaz de superar o antigo modelo de Direito, assim como enfrentou o constitucionalismo moderno. O diálogo com novas fontes de saberes, tanto entre países quanto entre grupos sociais, apenas permitiu agregar melhores condições à proteção da rede amazônica. Dessa forma, "a questão ambiental gera assim um processo de fertilizações transdisciplinares através da transposição de conceitos e métodos entre diferentes campos do conhecimento" (LEFF, 2010, p. 163).

É sobretudo entender que a diferença pode construir tanto quanto o homogêneo e o idêntico. Os povos originários exerciam, já antes mesmo da sociedade atual, uma relação ambiental harmônica. E a sociedade contemporânea 
ainda não despertou para essa necessidade, e pretensiosamente delega o vínculo com o meio ambiente, com destaque para a Floresta Amazônica, ao espanto de seu flagelo e destruição constante, sem que tome atitude ou se mobilize para evitar maiores danos.

\begin{abstract}
Os movimentos indígenas vêm aumentando de forma crescente o reconhecimento, a vigilância e os privilégios de um direito que regula a vida social indígena. Esta reivindicação é um meio de se opor a uma ordem normativa que não reconhece a diversidade e que penaliza as práticas que a constituem e se fundamenta na ideia de que o direito é um elementochave na estratégia do Estado para dissolver as particularidades dos povos e assegurar as condições que possibilitam o exercício da hegemonia. (GUERRERO, 1997, p. 81). (Tradução nossa). ${ }^{27}$
\end{abstract}

O pensar das comunidades tradicionais permite que a preservação florestal amazônica seja coerente e constante. Coerente com as diferenças de marcos constitucionais dos países da região Pan-Amazônica, havendo uma interlocução, uma abertura sistêmica entre constituições, para melhor definir como tutelar esse objeto jurídico. Ainda, o saber tradicional deve ser constante, para que não se perca de vista a importância desse espaço ambiental para as presentes e futuras gerações, de todos os grupos sociais e tradicionais.

Em comparação com o antigo paradigma constitucional, "[...] pode-se afirmar que o novo constitucionalismo iniciou um processo ativo de reinvenção das comunidades, ao reconhecer e redefinir as pluralidades nacionais, ainda que existam variações na forma como ele incorpora os direitos das comunidades tradicionais" (AVRITZER, 2017, p. 29). Cabe então ao novo modelo constitucional avançar para a inserção e aplicação efetiva dos saberes tradicionais na proteção ambiental das florestas, meios para fomentar esse tipo de capacitação, e estruturas legislativas não faltam, pois as próprias constituições dos países da região Amazônica dão espaço para algumas medidas.

Uma dessas medidas são os acordos internacionais que visem diretrizes ou que determinem políticas públicas internacionais ou internas. Chamar para participar de grupos, projetos e trabalhos, acordos e conferências internacionais que definam a

\footnotetext{
27 Los movimientos indígenas vienen planteando de una manera cresciente el reconocimiento, vigência y privilégios de un derecho proprio que regule la vida social indígena. Este reclamo es un médio para oponerse a un orden normativo que no reconece la diversidad y que penaliza las prácticas que la constituyen y se funda em la idea de que el derecho es una pieza clava en la estrategia del Estado para dissolver las particularidades de los pueblos y assegurar las condiciones que hacen posible el ejercicio de la hegemonía.
} 
proteção florestal, e os povos originários atendendo ao paradigma constitucional vigente, dando eficácia à norma constitucional. Isso demonstra a efetiva integração do conhecimento desses povos, que estão em isolamento, mas que, diante de algo em comum - o meio ambiente, trazem ao mundo jurídico a sociedade encerrada nos muros da racionalidade contemporânea, elementos que podem sustentar uma melhor simbiose entre a humanidade e suas técnicas com o ambiente e seus frutos.

A transmissão desses saberes ao mundo jurídico também se faz necessária; a pesquisa acadêmica, de campo, interdisciplinar entre as ciências, voltada para instrumentalizar o Direito e as demais ciências do "nosso mundo", é ferramenta que traduz a compreensão cultural dos grupos tradicionais. Será por meio da troca de saberes que conseguirá a cultura tradicional adentrar o projeto neoconstitucional da sociedade, conformatando-a para compreensão dessa sociedade constitucionalizada, participando e elevando a proteção florestal de forma objetiva. A Convenção sobre Diversidade Biológica de 1992 é um marco jurídico internacional para a implementação dessa integração e compartilhamento de conhecimentos, trazendo recomendações para observância do diálogo de saberes.

A educação ambiental evidenciada pelas constituições trabalhadas anteriormente compactua para disseminar o entendimento e a comunicação da sociedade com comunidades originárias. A educação é o instrumento que viabiliza entender as diferenças, as pluralidades sociais, dá a abertura, a alteridade, o respeito e o reconhecimento dos outros e suas diferenças e a possibilidade de se constituir novos laços. Em relação ao meio ambiente, possibilita-se que a cultura desses outros, até então desconhecida, possa fazer parte da vida individual e coletiva, com fim de preservar o meio ambiente. Dessa maneira "[...] com uma educação ambiental verdadeiramente adequada, completa e eficaz, é possível ocorrer uma modificação de comportamento [...]" (CARVALHO, 2017, p. 63), atendendo aos preceitos emanados nas constituições. A educação promove outro aspecto essencial para essa absorção plural dos costumes tradicionais ao sistema jurídico, uma postura ética capaz de reformular posicionamentos políticos e sociais tanto para a defesa dessas populações quanto para trazer ao contexto da vida prática de proteção ambiental as ideias por eles emanadas. Logo:

[...] a ética da responsabilidade objetiva uma reformulação dos princípios, no âmbito filosófico e um novo modelo para a educação, com a finalidade de conter o ímpeto humano de dominação. Nesse sentido, propugna-se por 
uma vida digna não apenas para a espécie humana, mas para a natureza como totalidade. (BENTES, 2012, p. 179).

Por fim, não menos importante é o papel das cortes constitucionais e as tomadas de decisões que reivindicam a atuação desses tribunais. As decisões proferidas sobre temas ambientais e constitucionais devem passar pelo crivo ou ao menos aceitar, em tal medida, a intercessão, o diálogo com essas fontes de saberes para proteção ambiental. Aqueles que interpretam a Constituição, em última instância, e retiram o sentido aplicável, quando deparado com esses fatos, devem estar "[...] dentro da ressignificação da vida e da reconstrução do mundo atual" (LEFF, 2010, p. 173), convergindo a dinâmica jurídica com o que foi absorvido dos povos originários.

A importância da atuação judicial é de confirmação tanto dos direitos desses povos em participar das tomadas de decisões internas e internacionais e buscar adaptar-se e atualizar seu sistema, diante das mais diversas situações expostas pelas sociedades. Portanto "[...] podemos afirmar que o novo constitucionalismo aumentou as prerrogativas do Judiciário e abriu caminho para seu crescente protagonismo" (AVRITZER, 2010, p. 33), que permite aos juízes nacionais e internacionais avaliarem a possibilidade de interferência, caso não sejam respeitados a normativa constitucional e os acordos internacionais, para implementar o diálogo com os saberes tradicionais.

Ou seja, desde a inauguração de um novo modelo constitucional pelos países latinos, em especial aqueles dentro da região da Pan-Amazônia, o papel dos países, em âmbito interno ou externo, é buscar uma proteção ambiental. Diálogos entre Estados, acordos internacionais, conferências, estudos promovidos por esses países são algumas das formas de intensificar e promover o que foi proposto como proteção ambiental nos próprios textos constitucionais, direta ou indiretamente vinculados à Floresta Amazônica. A consagração e a participação dos povos originários dessa região amazônica nada mais são do que dar a devida normatividade, efetividade jurídica e política de atores antes não vislumbrados. A participação dessas comunidades na salvaguarda desse patrimônio humano que é a Floresta Amazônica intensifica a tutela, além de permitir a participação de grupos excluídos pelo antigo modelo constitucional dos países. O neoconstitucionalismo, apesar de herdar a metodologia jurídica clássica, desvincula-se para atrair e incluir o pluralismo social que existe nos países da América Latina, e assim deve buscar 
sempre atualizar-se diante da necessidade social que ainda poderá surgir em outro momento paradigmático.

\section{CONSIDERAÇÕES FINAIS}

Dentro do que foi exposto nesta pesquisa, percebe-se que 0 neoconstitucionalismo é um modelo capaz de agregar mudanças sociais, agregando ainda a possibilidade de ampliar essa abertura sistêmica, quando se visualiza a integração dos saberes culturais dos povos originários. O novo constitucionalismo permite melhor olhar para as diferenças culturais internas dos países, trazendo para o ordenamento jurídico aquilo que melhor pode ser aproveitado no Direito, refletindo na integração internacional. O neoconstitucionalismo nasce da ruptura com o modelo constitucional americano e europeu, mas isso não quer dizer que nada foi aproveitado, e sim apenas que as concepções culturais e sociais que existem na Europa e na América do Norte não permitem contemplar a pluralidade social e as diferenças que existem. Logo, muitos desses grupos ficaram por bastante tempo fora da participação política e jurídica.

O novo constitucionalismo extrai do modelo constitucional a organização, mas percebe a necessidade de abrigar em seu texto novas concepções, integração e participação, não antes viabilizadas pelo constitucionalismo clássico. Em razão dessa virada comportamental das constituições, a participação popular, as ferramentas de controle de interesses majoritários e contramajoritários, a adesão a programas de integração regionais e internacionais ea participação dos povos originários passam a integrar bases importantes para a política e a juridicidade de um Estado.

Esses fatores permitiram que as relações entre países fossem estreitadas seja por interesses econômicos, políticos e sociais. Tais relações estão hoje inseridas não somente em planos de gestão interna, mas em uma agenda progressista com outros países em mesma situação. É o caso da região PanAmazônica, em que países possuidores de parcela dela se unem para geri-la e protegê-la, sem perderem suas soberanias e jurisdição, e, ao mesmo tempo, difundirem dados para a preservaçãoda floresta.

O Tratado de Cooperação Amazônica é o resultado dessa integração; uma governança ambiental, em prol da preservação da Amazônia multinível. Logo, a 
participação para proteger a floresta é dever de governos, instituições econômicas e da sociedade, dentro e fora do território geográfico dos Estados, o que permite a proposição de defesa ambiental alargada, de tutela do meio ambiente amazônico micro e macro.

Tal governança na floresta amazônica não seria possível sem uma abertura constitucional. O novo constitucionalismo dos países latinos apresenta-se como capaz de adaptar-se a esses eventos, com vistas à ampliaçãodo espectro de proteção de bens comuns, direitos e garantias de povos. Mas não é só, pois permite, também, conversar e trazer aos ordenamentos jurídicos conhecimentos interdisciplinares, filosóficos, tradicionais ou éticos, que permitam evoluir e expandir a salvaguarda da floresta.

A axialidade entre os saberes originários, tradicionais e o direito permite a construção de uma base mais sólida de tutela, ante ao manejo de conhecimentos, outrora esquecidos e agora utilizados em prol do ambiente. O neoconstitucionalismo avança em permitir uma inter e transdisciplinaridade, principalmente quando observadas as constituições andinas, integradoras do conhecimento de uma população ainda presente que mantém a cultura de povos anteriores à colonização ou, como no caso da Constituição brasileira, que permite ao intérpretea modulaçãodo sentido normativo.

Esse novo modelo surge integrando o meio ambiente no rol de direitos constitucionais, o que garante uma elevada e grande intenção de proteção. Dessa forma, os países que desde 1980 passaram a esse novo paradigma incluíram em suas normas a troca de saberes e a proteção ambiental, autorizando todo o conhecimento das comunidades tradicionais que beneficiem a proteção da Floresta Amazônica. A troca de saberes tradicionais com a organicidade jurídica põe aos Estados, internamente, a possibilidade de incluírem esses povos na participação política e jurídica. Em termos internacionais, há maior integração e efetivação das normas constitucionais, de acordos e convenções assinadas entre esses países, indo ao encontro das propostas internacionais de proteção ambiental firmadas por esses países para proteger o meio ambiente. Algumas das formas de absorção dessas culturas estão dispostas desde o preâmbulo até capítulos em separado e princípios constitucionais. A educação, as políticas públicas, os acordos internacionais que tragam a efetiva participação dos povos originários e as cortes constitucionais são exemplos expostos pelas constituintes e que essa pesquisa 
ressalta para afirmar que o neoconstitucionalismo é o modelo mais adaptável e que permite se moldar em consonância com seu povo e seus interesses, sem contudo deixar de se integrar e interagir com outros países na proteção ambiental, especialmente os que estão ligados pela proteção da Floresta Amazônica.

\section{REFERÊNCIAS}

ALLUT, A. G. O conhecimento dos especialistas e seu papel no desenho de novas políticas pesqueiras. In: DIEGUES, A. C. (Org.). Etnoconservação: novos rumos para a proteção da natureza nos trópicos. 2. ed. São Paulo: Hucitec e NUPAUB, 2001, p. 101-123.

AVRITZER, Leonardo. O novo constitucionalismo latino-americano, uma abordagem política. In: AVRITIZER, Leonardo; GOMES, Lilian Cristina Bernardo; MARONA, Marjorie Corrêa; DANTAS, Fernando Antônio Carvalho. (Org.). 0

constitucionalismo democrático latino-americano em debate: soberania, separação de poderes e sistemas de direitos. Belo Horizonte: Autêntica, 2017, p. 1942.

BARBOSA, Maria Lúcia; TEIXEIRA, João Paulo Allain. Neoconstitucionalismo e novo constitucionalismo latino-americano: dois olhares sobre igualdade, diferença e participação. Revista Direito e Práxis, v. 8, n. 2, 2017.

BARROSO, Luís Roberto. O novo direito constitucional brasileiro: contribuições para a construção teórica e prática da jurisdição constitucional no Brasil. Belo Horizonte: Fórum, 2013.

BARROSO, Luís Roberto. Neoconstitucionalismo e constitucionalização do Direito (o triunfo tardio do Direito Constitucional no Brasil). Themis: revista da ESMEC, v. 4, n. 2, p. 13-100, 2006.

BENTES, Hilda Helena Soares. Prometeu liberto: nova ética para o homem da 
técnica segundo Hans Jonas. Veredas do Direito: Direito Ambiental e desenvolvimento sustentável, Belo Horizonte, v. 9, n. 18, p. 169, mar. 2013. ISSN 21798699. Disponível em: http://www.domhelder.edu.brl. Acesso em: 10 jan. 2019.

BIZAWU, Kiwonghi; CUNHA, Lorena R. B. O Equador e a Região Amazônica. In: COSTA, Beatriz Souza (Org.). Pan-Amazônia: o ordenamento jurídico na perspectiva das questões socioambientais e da proteção ambiental. Belo Horizonte: Dom Helder, 2016, p. 125-168.

BOLÍVIA. Constitución Política del Estado. El Alto de La Paz: 2009. Disponível em: https://constituteproject.org/. Acesso em: 15 set. 2016.

BRASIL. Constituição da República Federativa do Brasil. Brasília: Senado Federal, Centro Gráfico, 1988.

CARVALHO, Vânia. Á.O.. Educação ambiental e desenvolvimento sustentável: possibilidade transformadora sob a égide da paideia. Dissertação (Mestrado em Direito). Escola Superior Dom Helder Câmara. Belo Horizonte, 2017. 143 p.

CATTONI, Marcelo A. de Oliveira; GOMES, David Francisco Lopes. A Constituição entre o Direito e a política: novas contribuições para a teoria do poder constituinte. In: OLIVEIRA, M. A. Cattoni de (Org.). Constitucionalismo e história do Direito. Belo Horizonte: Pergamum, 2011, v.1, p. 125-159.

CERQUEIRA, M.. A Constituição na história: origem \& reforma. EditoraRevan, 1993.

CHUEIRI, Vera Karam de; GODOY, Miguel G.. Constitucionalismo e democracia soberania e poder constituinte. Revista Direito GV, [S.I.], v. 6, n. 1, p. 159-174, jan.2010. ISSN 2317-6172. Disponível em: http://bibliotecadigital.fgv.br/ojs/index.php/revdireitogv/article/view/24214/22987. Acesso em: 26 fev. 2019.

COLOMBIA. Constitución política de Colombia. Bogotá, Colombia: Leyer, 1991. Disponível em:http://www.corteconstitucional.gov.co/inicio/Constitucion\%20politica\%20de\%20C olombia.pdf. Acesso em: 15 set. 2016.

COSTA, Beatriz Souza. A Amazônia venezuelana. In: In: COSTA, B. S..(Org.). PanAmazônia: o ordenamento jurídico na perspectiva das questões socioambientais e da proteção ambiental. Belo Horizonte: Dom Helder, 2016, v. 1, p. 295-321.

CUNHA, Lorena R. B. da. O Suriname e a região amazônica. In: COSTA, B. S. (Org.). Pan-Amazônia: o ordenamento jurídico na perspectiva das questões socioambientais e da proteção ambiental. Belo Horizonte: Dom Helder, 2016, v. 1, p. 265-294.

DALLARI, Dalmo de Abreu. Elementos de teoria geral do Estado. São Paulo: Saraiva, 2011.

EQUADOR. Constitución de la República delEcuador. Quito: 2008. Disponível em: https://www.oas.org/juridico/mla/sp/ecu/sp ecu-int-text-const.pdf. Acesso em: 15 
set. 2016.

GUERRERO, Diego A. Iturralde. Demandas indígenas y reforma legal: retos y paradojas. Alteridades, n. 14, p. 81-98, 1997.

GUIANA. ConstitutionoftheCo-OperativeRepublicofGuyanaAct. 1980. Disponível em: https://www.oas.org/juridico/spanish/mesicic2 guy constitution.pdf. Acesso em: 26fev. 2019.

HELD, David; MCGREW, Anthony. The Great Globalization Debate:An Introduction. In: HELD, David; MCGREW, Anthony (Org). The Global Transformations Reader: An Introduction to the Globalization Debate, Cambridge, England: Polity Press, 2003.

KALIL, Ana Paula Maciel Costa; FERREIRA, HelineSivini. A dimensão socioambiental do estado de direito. Veredas do Direito: Direito Ambiental e Desenvolvimento Sustentável, Belo Horizonte, v. 14, n. 28, p. 329-359, jun. 2017. ISSN 21798699. Disponível em: http://www.domhelder.edu.br/revista/index.php/veredas/article/view/1010/549. Acesso em: 4 abr. 2019.

KOKKE, Marcelo. A Bolívia e a Amazônia. In: COSTA, B. S.. (Org.). Pan-Amazônia: o ordenamento jurídico na perspectiva das questões socioambientais e da proteção ambiental. Belo Horizonte: Dom Helder, 2016, v. 1, p. 21-71.

LEFF, Enrique. Aventuras da epistemologia ambiental: da articulação das ciências ao diálogo de saberes. Tradução de Silvana Cobucci Leite. São Paulo: Cortez, 2012.

LEFF, E..Epistemologia ambiental. Tradução de Sandra Valenzuela. 5.ed. São Paulo: Cortez, 2010.

LEFF, E..Saber ambiental: sustentabilidade, racionalidade, complexidade, poder. Saberes. Tradução de Lúcia Mathilde Endlich Orth. 11. ed. Petrópolis: Vozes, 2015.

MACHADO, P. A. L. Direito ambiental brasileiro. 25. ed. São Paulo: Malheiros, 2017.

MACHADO, P. A. L. Introdução. In: COSTA, Beatriz Souza (Org.). Pan-Amazônia: o ordenamento jurídico na perspectiva das questões socioambientais e da proteção ambiental. Belo Horizonte: Editora Dom Helder, 2016.

McGROW, Anthony G. Conceptualizing global politics. In: McGROW, Anthony G.; LEWIS, Paul G. et al. Global politics. Cap. 1. Cambridge: Polity Press, 1992. p. 1 28.

MIGNOLO, Walter. The darker side of western modernity: global futures, decolonial options. Duke University Press, 2011.

OLIVEIRA, Ana Gita; ANDRELLO, Geraldo. Dossiê IPHAN 7: cachoeira de lauaretê. Brasília: Iphan, 2007.

OLIVEIRA, Márcio L.; BRITO, Franclin J. S. de. A Guiana e a Amazônia. In: COSTA, 
B. S.. (Org.). Pan-Amazônia: o ordenamento jurídico na perspectiva das questões socioambientais e da proteção ambiental. Belo Horizonte: Dom Helder, 2016, v. 1, p. 169-182.

OLIVEIRA, Márcio L.; SAMPAIO, José A. L. A Amazônia peruana. In: COSTA, B. S.. (Org.). Pan-Amazônia: o ordenamento jurídico na perspectiva das questões socioambientais e da proteção ambiental. Belo Horizonte: Dom Helder, 2016, v. 1, p. 237-264.

OLIVEIRA, Márcio Luís de. A constituição juridicamente adequada. Belo Horizonte: D'Plácido, 2016.

PERU. Constitución Política del Perú. 1993. Disponível em:

http://www4.congreso.gob.pe/ntley//magenes/Constitu/Cons1993.pdf. Acesso em: 28 fev. 2019.

RAMOS, A. V. G. F. F. A Amazônia colombiana. In: COSTA, Beatriz Souza. (Org.). Pan-Amazônia: 0 ordenamento jurídico na perspectiva das questões socioambientais e da proteção ambiental. Belo Horizonte: Dom Helder, 2016, v. 1, p. 97-124.

RAMOS, Elisabeth Christmann. Educação ambiental: origem e perspectivas. Educar emRevista, v. 17, n. 18, p. 201-218, 2001.

REI, Fernando C.F..Lei ambiental internacional e governança ambiental global: influências do sul.Veredas do Direito: Direito Ambiental e Desenvolvimento Sustentável, Belo Horizonte, v. 15, n. 32, p. 143-165, set. 2018. ISSN 2179-8699. Disponível em: http://www.domhelder.edu.br/. Acesso em: 15 mar. 2019.

REZENDE, ElcioNacur. A Amazônia brasileira. In: COSTA, Beatriz Souza. (Org.). Pan-Amazônia: o ordenamento jurídico na perspectiva das questões socioambientais e da proteção ambiental. Belo Horizonte: Dom Helder, 2016, v. 1, p. 73-97.

SOLA, Fernanda et al. Responsabilidade civil ambiental nos países integrantes do tratado de cooperação amazônica. In: XV CONGRESSO NACIONAL DO CONPEDI.Manaus: Boiteux. 2007.

SURINAME. The Constitution of The Republic of Suriname. 1992. Disponível em: http://www.unesco.org/education/edurights/media/docs/dfcff4209dad7879549a7d46d c0bcbf82919c591.pdf. Acesso em: 28 fev. 2019.

TOLEDO, André de Paiva. A Guiana Francesa e a Amazônia. In: COSTA, B.S.. (Org.). Pan-Amazônia: o ordenamento jurídico na perspectiva das questões socioambientais e da proteção ambiental. Belo Horizonte: Dom Helder, 2016, v. 1, p. 183-236.

TOLENTINO, Zelma Tomaz; OLIVEIRA, Liziane Paixão S. Pachamama e o direito à vida: uma reflexão na perspectiva do novo constitucionalismo latinoamericano. Veredas do Direito: Direito ambiental e Desenvolvimento Sustentável, Belo Horizonte, v. 12, n. 23, p. 23, out. 2015. ISSN 21798699. Disponível em: 
http://www.domhelder.edu.br/revista/index.php/veredas/article/view/393/450. Acesso em: 4 abr. 2019.

UNESCO. Declaração universal sobre a diversidade cultural. 2001. Disponível em:

http://www.unesco.org/new/fileadmin/MULTIMEDIA/HQ/CLT/diversity/pdf/declaration cultural diversity pt.pdf. Acesso em: 10 abr. 2019.

VENEZUELA. Constitución de la República Bolivariana. 1999. Disponível em: https://www.oas.org/juridico/mla/sp/ven/sp_ven-int-const.html. Acesso em: 31 jul. 2019.

WOLKMER, Antônio Carlos. Introdução aos fundamentos de uma teoria geral dos "novos" direitos. In: WOLKMER, Antônio Carlos; LEITE, José Rubens Morato (Org.). Os "novos" direitos no Brasil: natureza e perspectivas - uma visão básica das novas conflituosidades jurídicas. 2. ed. São Paulo: Saraiva, 2012.

WOLKMER, Antônio Carlos. Ética da sustentabilidade e direitos da natureza no constitucionalismo latino-americano. In: LEITE, José Rubens Morato; PERALTA, Carlos. Perspectivas e desafios para a proteção da biodiversidade no Brasil e na Costa Rica. São Paulo: Planeta Verde, 2014, p. 67-84. 